\title{
Analisa Perancangan Sistem Informasi E-Commerce Dengan Metode Object Oriented dan ISO 9126 pada PT.Samudera Semesta Sejahtera
}

\author{
Tanto Heryanto ${ }^{1}$, Yakub $^{2}$. \\ ${ }^{1,2}$ Buddhi Dharma University, Information System, Banten, Indonesia
}

\begin{tabular}{l}
\hline SUBMISSION TRACK \\
\hline Received 20 June 2019; \\
Revised 20 July 2019; \\
Accepted 10 September 2019; \\
Available online 20 September 2019 \\
KEYWORD \\
\hline E-Commerce \\
ISO 9126 \\
Object Oriented \\
KORESPONDENSI \\
\hline E-mail: tantooheryanto@ gmail.com \\
y44kub@ yahoo.com \\
\hline
\end{tabular}

\section{INTRODUCTION}

Information system now a days are incrising significantly, and a lot of people use it. Information system is helping to work, and also making it a benefit for a company. one of the system information that has been developed is web based or e-commerce. Information system or e-commerce in PT. SSS need a system information that support the business. PT. SSS established on 2000 in North roa malaka no 53 jakarta. This company contains Manager Import, Manager Export, Manager Accounting, Document Import, Document Export, Staff Accounting, Operasional. the main problem of PT. SSS are on export document ; (a) Still promoting service via telephone from the company's email or phone. (b) Sometimes the employee loss the document that need in

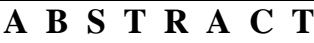

PT. Samudera semesta sejahtera is a freight forwarding company that handle export and import. The main problem is the document of export such as : there still promoting their service via telephone by the office and by the email. Also sometimes they miss the documents that sometimes will be need back. Manual booking, e-commerce using unified modelling language (UML); activity diagram, usecase diagram, sequence diagram, and class diagram. Using object oriented and iso 9126, the programming language that use in this e-commerce system is PHP and database MySQL. The result of this e-commerce is for business, making easier to search data or information, and printing a report.
\end{abstract}

the future. (c) Manual booking by phone of email.Based on the issue that document's export have, so the owner of the company have an idea to develop the website that consist of activity diagram. Programing programme that need to use is PHP. The database that use is MYSQL using object oriented. This aplication being tested using software ISO 9126 to measuring the quality of the software. Information system of ecommerce hopefully meets customer's requirement.

\section{LITERATURES REVIEW}

The previous research that use for the guidance is for supporting this problem. Researched about ISO 9126 and object 
oriented is having a lot of people that do it, especially on collagues. The example is [1]. On that research is being explain that using manual system is the weakness of human being. the media promotion still using the pamflete, advertisment on the news paper, using baliho. The way the company promoting seems not effective, the way out is to creating new website system, the method that need to be develop is using method ( TERAPAN) on this system, is to implement analisyst system with object oriented also for quality software for implementated ISO 9126

\section{FRAMEWORK}

Following are the considerations made :

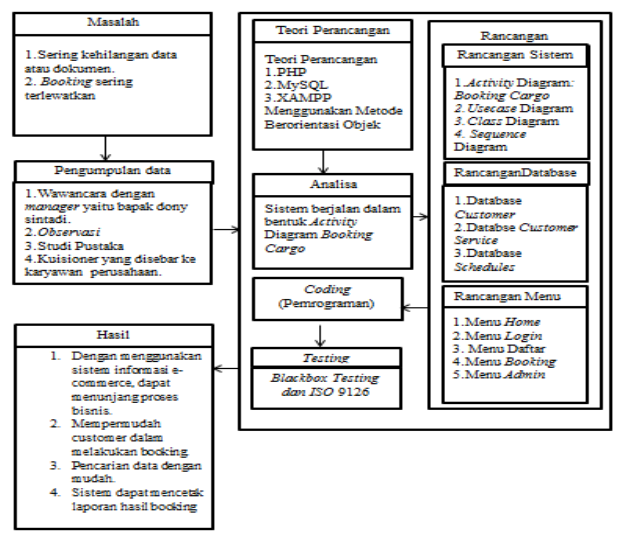

\section{Image. 1 Framework}

\section{METHODS}

\subsection{Definition Of E-Commerce}

Electronic commerce is " sell-buy things", sellingand offering a service thru electronic system. Such as radio, television, andcomputer network or internet. So ecommerce is a selling and buying transaction that done on internet where the internet $\mathrm{I}$ is using for a place to do that process. Using this system can be advantage betweem the customer and the seller [2].

\subsection{Objek Oriented}

Object oriented is "a programme that will be oriented by object", the purpose of OOP being created is for make easier of the programmer to develop the program with following the daily model. So with this implemented of object oriented make developing the software become easier [3].

\subsection{CodeIgniter}

Codeigniter is a framework of PHP programing language that created by rick ellis on 2006 whom also thefounder of ellis, framework php that created based on model view controller. With model view controller ( mvc), make a possible way to separate layer application logic and precentation. So the developer of the webmaster can be focus on the core of the web [5] in code igniter, there is some implementation of MVC as below :

a. Model

A based on code of OOP class that use to do database.

b. View

Is a view html/xml or php to showing the data on browser

c. Controller

A code program for oop class that use for controlling application flow ( to control model and view )

\subsection{ISO 9126}

ISO 916 is a quality product of softwar, model, characteristic and a metric that use for measuring for the quality of a software [4] standar of ISO 9126 already update for making better computer's software. 
Table 1. Software Quality Measurement ISO 9126

\begin{tabular}{|c|c|c|}
\hline Variabel & Sub-Variabel & Indikator Pengukuran \\
\hline \multirow[t]{4}{*}{ Functionality } & Suitability & Kesesuaian sistem dengan kebutuhan \\
\hline & Accuracy & Keakuratan informasi yang dihasilkan oleh sistem \\
\hline & Security & Keamanan data dan pengguna \\
\hline & Interoperability & $\begin{array}{l}\text { Integritas dan akses sistem dengan perbedaan } \\
\text { teknologi yang digunakan }\end{array}$ \\
\hline \multirow[t]{3}{*}{ Reliability } & Maturity & Rendahnya tingkat kes alahan dalam sistem \\
\hline & Fault tolerance & $\begin{array}{l}\text { Kemampuan untuk berfungssi seperti biasa setelah } \\
\text { terjadi kes alahan }\end{array}$ \\
\hline & Recoverability & $\begin{array}{l}\text { Kemampuan sistem untuk mengatasi kes alahan yang } \\
\text { terjadi }\end{array}$ \\
\hline \multirow[t]{4}{*}{ Usability } & Understandibility & Kemudahan sistem untuk dipahami \\
\hline & Lsamability & Kemudahan sistem untuk dipelajari \\
\hline & Operability & Kemudahan sistem untuk dioperasikan \\
\hline & Attractiveness & Kenyamanan pengguna dalam menggunakan sistem \\
\hline \multirow[t]{2}{*}{ Efficiency } & Time Behavior & Kecepatan respon dan waktu pengolahan \\
\hline & $\begin{array}{l}\text { Resource } \\
\text { Behavior }\end{array}$ & Kesesuaian penggunaan sumber daya \\
\hline
\end{tabular}

Source : Jurnal Sains, Teknologi dan Industri Vol.13,No.2 Juni 2016 ISSN 1693-2390

\subsection{Unified Modelling Language}

Is a programming language that using in the industry to make a definition about requirement, analysis and making a design, also for an illustrated in object's oriented program. UML cannot decide that method that we can use on system, but only a temporary decision that can be accepted for the modeling . in UML there is 13 kinds of diagram that being combined into 3 category [3] : structure diagram, behavior Diagram and interaction diagram. In UML, there is much diagram that we can use, such as : Usecase diagram, Activity diagram, Sequence diagram and Class diagram.

\subsection{Definition Of Web}

Web is " a system with an information that containing words, picture, videos, voices, etc and this is keep in a website's server that is being available on hypertext. Web can be open by a client;s website software that is call by browser.

\subsection{Definition Of Data}

Data are all information that user can get from someone whom user can make them a respondence or anything comes from document, that can be preferred as a note or other form for research [7].

\subsection{Definition Of Informasi}

Information is a data that already compiled to giving some data and help to make a better decision as a quality and quantity fro adjusting the information. Information based on French language that is informacion. That word was taken on latin language "informationem" which has can be described as " concept or idea" [8].

\section{RESULT}

Data colect by result of respondent instrument (questionnaire) will calculate with persentage :

$$
\% \text { skor }=\frac{\text { actualscore }}{\text { idealskor }} \times 100 \%
$$

As data analysis from questionnaire, here the result of quality testing based on 4 aspect of soft ware ISO 9126:

Table. 2 Conversion Scale Likert

\begin{tabular}{|c|c|c|}
\hline No & $\%$ & Kriteria \\
\hline 1 & $0,00-20,00$ & Tidak Baik (1) \\
\hline 2 & $20,01-52,00$ & Kurang Baik (2) \\
\hline 3 & $52,01-68,00$ & Cukup Baik (3) \\
\hline 4 & $68,01-84,00$ & Baik (4) \\
\hline 5 & $84,01-100$ & Sangat Baik (5) \\
\hline
\end{tabular}

Table. 3 Result ISO 9126

\begin{tabular}{|l|l|l|l|l|}
\hline Aspek & Skor Aktual & Skor Ideal & \%Skor Aktual & Kriteria \\
\hline Functionality & 174 & 180 & $96,66 \%$ & Sangat Baik \\
\hline Usability & 562 & 750 & 74,93 & Baik \\
\hline Efficiency & 1363 & 1900 & $71,73 \%$ & Bailk \\
\hline
\end{tabular}


Forth aspect of Reliability use LoadImpact :

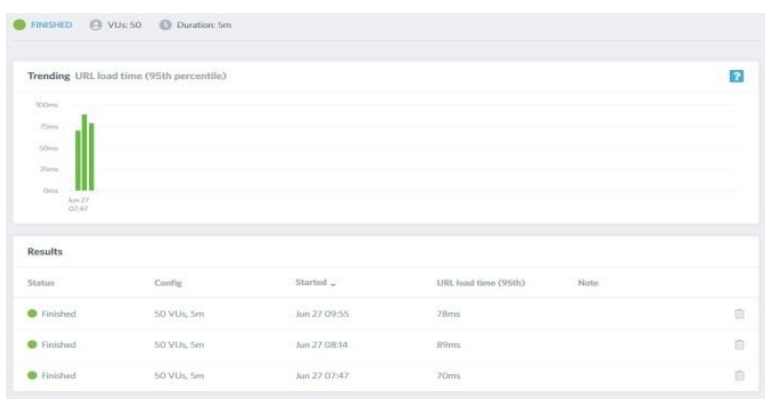

Image. 2 Test Reliability

After test with Singapore server accsess, during 5 minutes for access speed like request and response Vus degree or same as 50 users and get first load time testing score with standart method 70ms ( second mille), second testing use standart method $89 \mathrm{~ms}$ (second mille), third testing get $78 \mathrm{~ms}$ (second mille), the conclusion web speed average is $70 \mathrm{~ms}$. Standart method as same as load method.

\section{DISCUSSION}

\subsection{Design analysis with usecase diagram}

Usecase diagram that use in this system explain about proposal system to simpllyfy system to advise

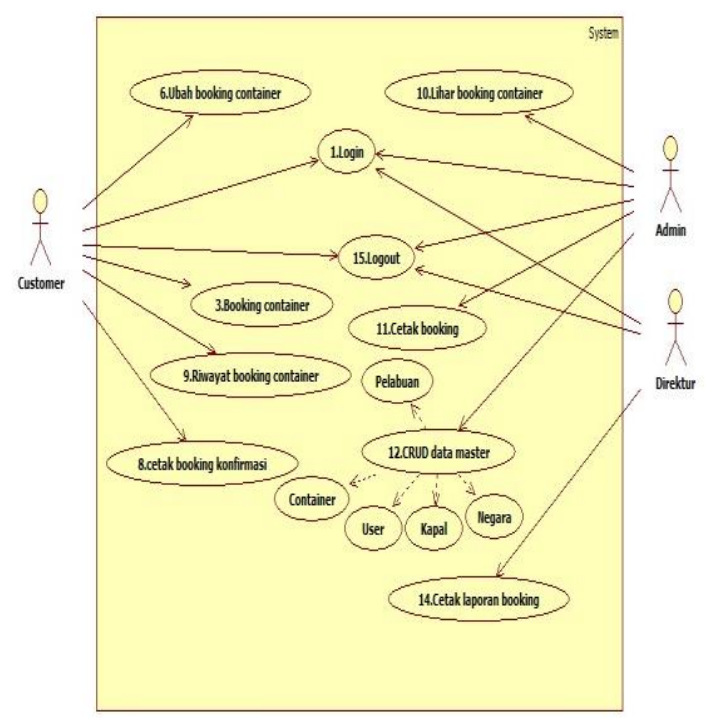

Image. 3 Usecase Diagram

\subsection{Activity Diagram}

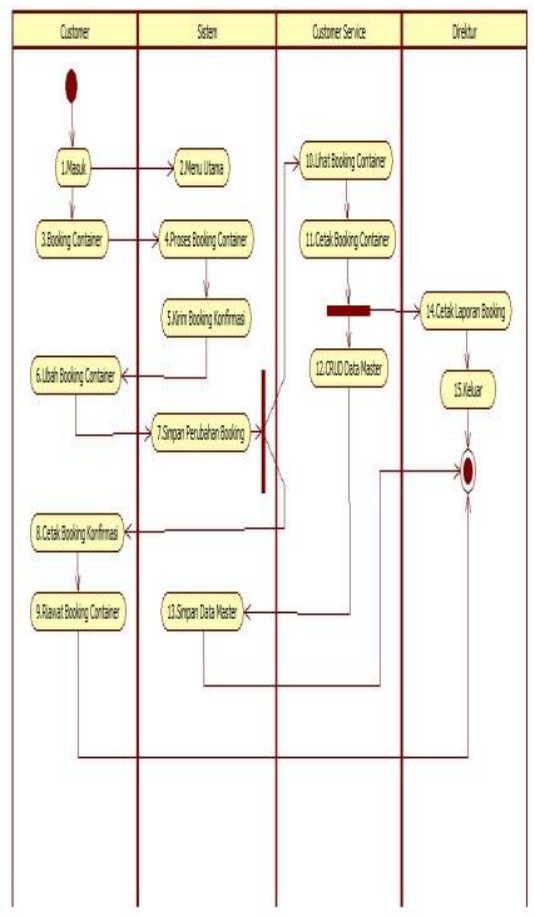

Image. 4 Activity Diagram

\subsection{Sequence Diagram}

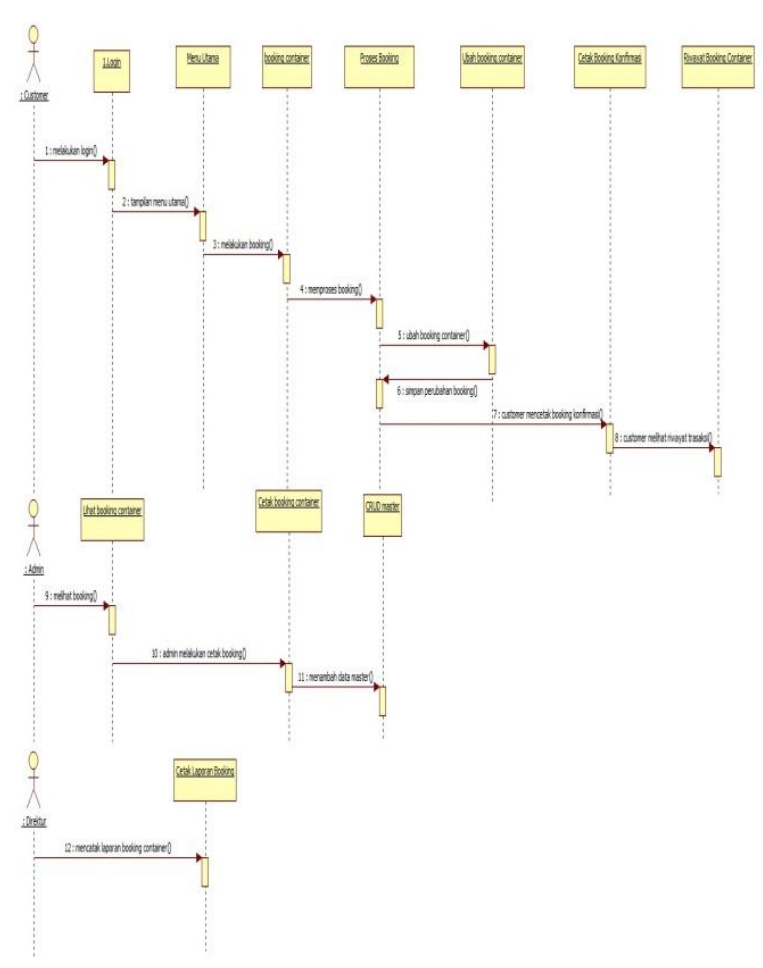

Image 5. Sequence Diagram 


\subsection{Class Diagram}

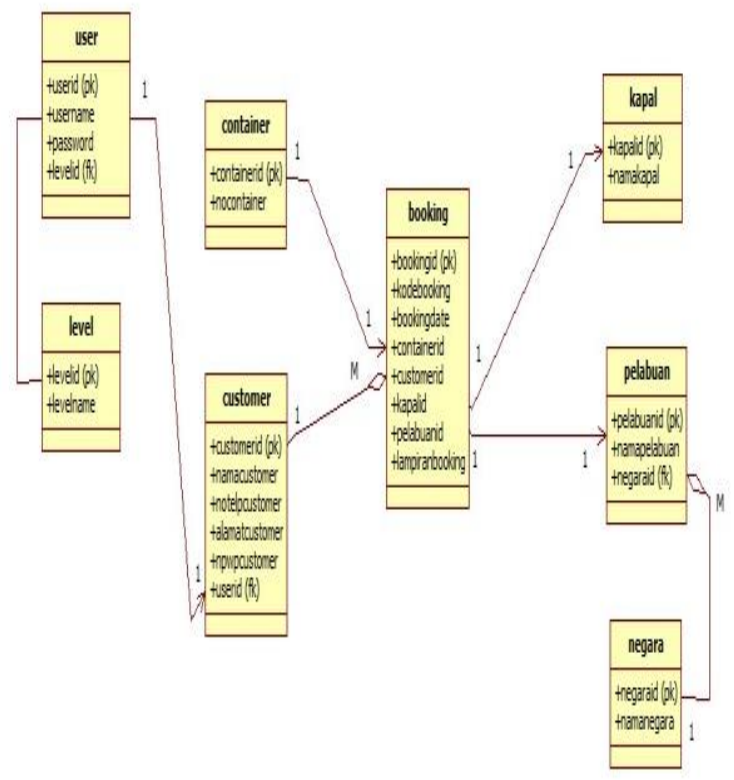

Image. 6 Class Diagram

\subsection{User Interface}

The following are some of the user interfaces / views of website have been created or implemented :

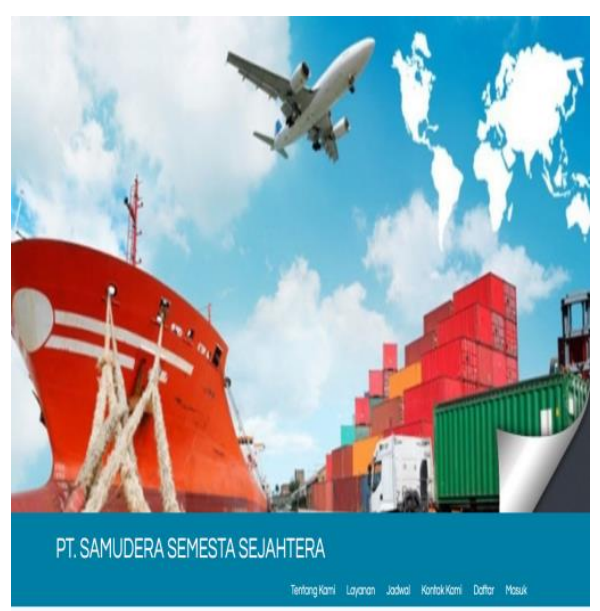

Layanan Terlaris

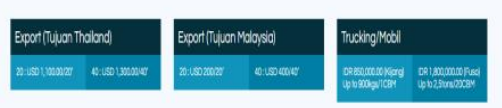

Image. 7 Main Menu Design

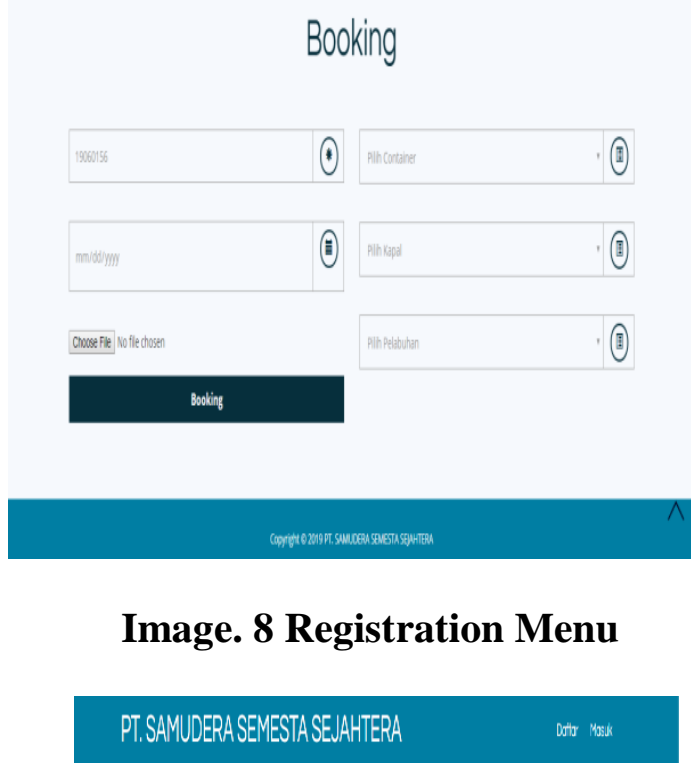

Dattar

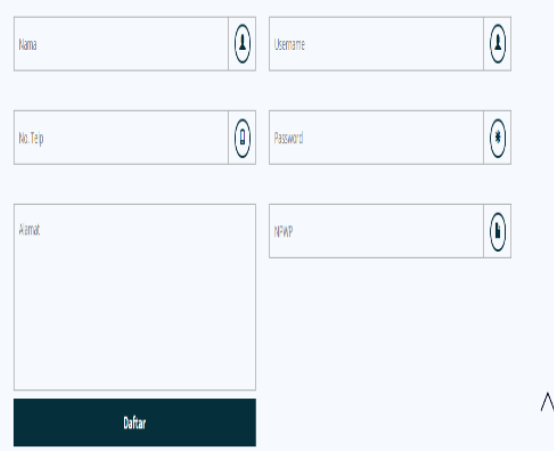

Image. 9 Booking Menu Design

PT. SAMUDERA SEMESTASEJAHTERA

Daftar Booking

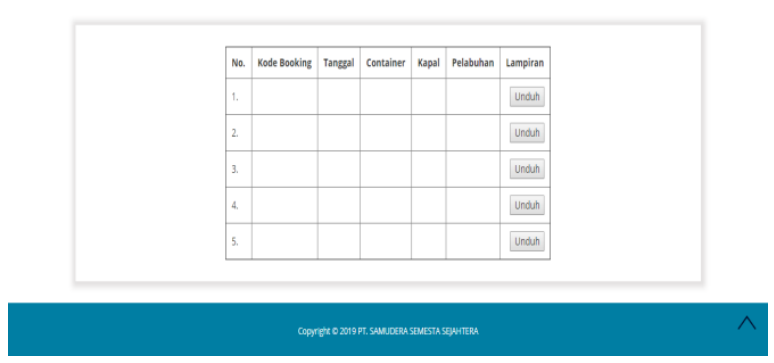

Image. 10 Booking Menu Design 


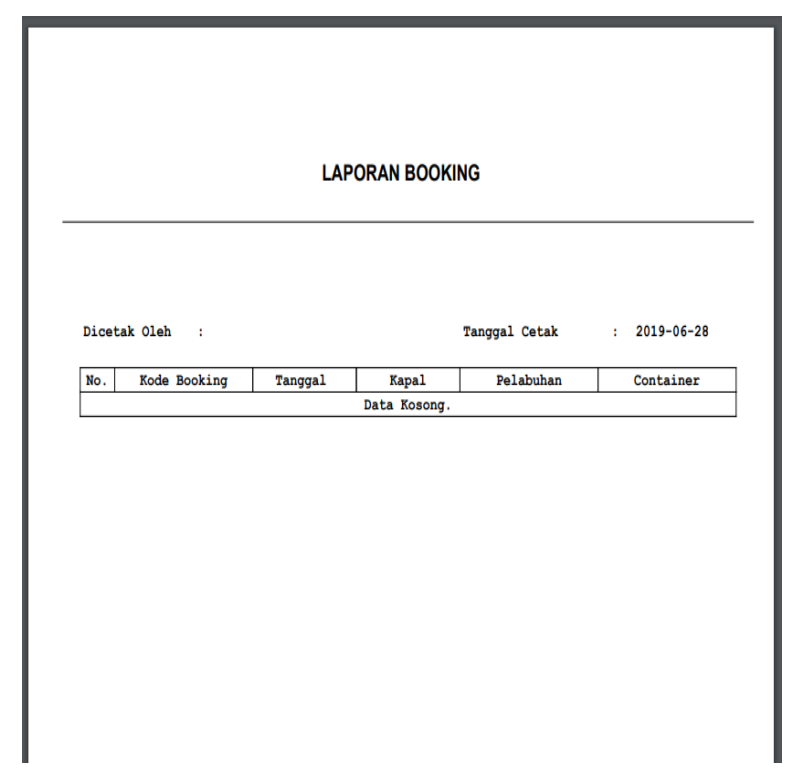

Image. 11 Report Design

\section{CONCLUSION}

Based on result information system design ecommerce in PT. SSS the conclusion is :

a. Information system e-commerce that build up can increase export and import business

b. Information system e-commerce can simplify customer do booking and access website without time and space

c. Simplify use to seacrh data or information they need

d. Information system e-commerce, owner can print report for booking confirmation and do not worry if data can not find or damaged.

e. Quality result test based aspect in ISO 9126, SUCH :

1. SOFTWARE QUALITY aspect functionality show that function suitable for demand, with percentage $96,66 \% 9$ very good)

2. Software quality usability aspect in good category with percentage $74,93 \%$

3. Result reliability use singapore acsess server with 50 respondent and get first load and get first load time testing score with standart method $70 \mathrm{~ms}$ (second mille), second testing use standart method $89 \mathrm{~ms} 9$ second mille), third testing get $78 \mathrm{~ms}$ (second mille), the conclusion web speed average is $70 \mathrm{~ms}$. The conclusion web speed access $70 \mathrm{~ms}$ (second mille)

4. Software quality efficiencygood enough with percentage score $71,73 \%$ 


\section{REFERENCES}

[1] Diki Susandi dan Sukisno, "Sistem Penjualan Berbasis E-Commerce Menggunakan Objek Oriented pada Distro Dlapak Street Wear", Jurnal Sistem Informasi, Vol. IV, 2017, pp.5-8.

[2] Wong, Jony. Internet Marketing for Beginners, Jakarta: Elex Media Komputindo, 2010.

[3] A.S Rosa, dan M.Shalahuddin, Rekayasa Perangkat Lunak Struktur dan Berorientasi Objek, Bandung : Informatika, 2014.

[4] Rafa E. Al-Quataish, Model Kualitas ISO 9126, International Organization For Standardization, 2010.

[5] Raharjo, dan Budi, Belajar Otodidak Framework CodeIgniter, Bandung : Informatika, 2015.

[6] Simarmata, Rekayasa Perangkat Lunak, Yogyakarta: Andi, 2010

[7] Rusdiana dan Moch.Irfan, Sistem Informasi Manajamen, Bandung : Pustaka Setia, 2014.

[8] Marshall B.Romney, dan Paul John Stinbart, Sistem Informasi Akuntansi Berbasis ISO 27001, Surabaya : ITS Press, 2015.

\section{BIOGRAPHY}

Tanto Heryanto, Graduated from the Information Systems Study Program (S1) in the Enterprise System, 2019.

Yakub, lecturer at the Information Systems Study Program at the Buddhi Dharma University, Tangerang. Graduated from S1 Information Systems STMIK Widuri Jakarta, 2002, Masters in Computer Eresha School of Information Technology, 2005, Masters in Management at Budi Luhur University, 2008, Doctoral Degree in the Islamic University of Nusantara Bandung, 2014. 